\title{
New evidence of feathers in the Crato Formation supporting a reappraisal on the presence of Aves
}

\author{
JULIANA M. SAYÃO ${ }^{1}$, ANTONIO A.F. SARAIVA ${ }^{2}$ and ANGELICA M.K. UEJIMA ${ }^{1}$ \\ ${ }^{1}$ Núcleo de Ciências Biológicas, Centro Acadêmico de Vitória, Universidade Federal de Pernambuco (CAV-UFPE) \\ Rua do Alto Reservatório s/n, Bela Vista, 55608-680 Vitória de Santo Antão, PE, Brasil \\ ${ }^{2}$ Departamento de Ciências Físicas e Biológicas, Universidade Regional do Cariri \\ Rua Cel. Antônio Luiz, 1161, 63105-000 Crato, CE, Brasil \\ Manuscript received on October 5, 2010; accepted for publication on December 22, 2010
}

\begin{abstract}
The preservation of delicate structures such as feathers is very rare in the paleontological record, due to the fragility of their components. Fossil feathers have been reported from approximately 50 deposits around the world, from the Late Jurassic to the Pleistocene. In Brazil initial findings consisted of a primary feather of a large bird found in the Tremembé Formation. Other occurrences are preserved in the Crato Formation, where several symmetrical and one single asymmetrical feather was found. Based on three new specimens and reassessing further feather occurrences we cannot confirm the presence of volant Aves in this deposit. The presence of an asymmetrical feather without barbules and hooks hints at the previous existence of a flightless animal within this deposit, possibly a flightlessness bird or a non-avian theropod. Conversely, the presence of a feather from morphotype II present in Tyrannosauroidea, Compsognathidae, Therizinosauroidea and Dromeosauridae, points to a non-theropod origin. Since there are no confirmed records of birds and other feathered archosaurs in the region to date, more evidence is required to identify the animal from which these structures originated.
\end{abstract}

Key words: Araripe Basin, Crato Formation, Cretaceous, feathers, theropod.

\section{INTRODUCTION}

Feathers are among the most complex integumentary appendages found in any vertebrate (Lucas and Stettenheim 1972, Bereiter-Hahn et al. 1986). They have complex branched structures, grown from their bases by a unique mechanism, and come in an astonishing variety of shapes, sizes, structures, and colors (Prum and Brush 2002, Prum and Williamson 2001). Feather structures are diverse in their appearance and function. Five main categories of feather are recognized today: contour feathers (body feathers, remiges and rectrices) and down feathers, semiplumes, filoplumes, and bristles (Prum 1999). These complex integumentary append-

Proceedings of the Third Gondwanan Dinosaur Symposium Correspondence to: Juliana Manso Sayão

E-mail: jmsayao@gmail.com ages are present in birds and also in some other theropod dinosaurs. A number of extremely well-preserved coelurosaurians from the Early Cretaceous of China (Chen et al. 1998, Ji et al. 1998, Xu et al. 1999a, b, 2000, 2001, Zhou and Wang 2000, Zhou et al. 2000, Norell et al. 2002, Norell and Xu 2005) have shown convincingly that feathers have their origins within theropod dinosaurs. They are composed primarily of keratin, which consists of insoluble microscopic filaments that are embedded in a proteinaceous matrix (Kellner 2002, Hudon 2005). Previous investigations have concluded that fossil feathers are preserved as carbonaceous residues in the majority of localities (Davis and Briggs 1995). Others pointed that some of these carbonized traces are composed of feather-degrading bacteria (Martill and Filgueira 1994), although recent studies suggest 
that some fossil feathers are preserved as melanosomes (Vinther et al. 2008, 2010).

The preservation of fossil feathers has been reported from about 50 deposits around the world ranging from the Late Jurassic to the Pleistocene in age (Buffetaut et al. 2002, Schweigert et al. 2009). Despite all these occurrences, the Cretaceous record is relatively sparce. In Brazil the first fossilized feather discovery belonged to the primary feather of a large bird reported from the Tremembé Formation (Oligocene), close to the city of Taubaté (Shufeldt 1916). Later other findings were published from these deposits, which reported the presence of isolated feathers imprints (Silva Santos 1950) and several feathers associated to the skeleton of a Taubacrex granivora (Alvarenga 1988). Further evidence comes from the state of Pará, in the north of Brazil (Ackermann 1964). All other occurrences are restricted to the Crato Formation where the findings began with the description of a small flight feather (Martins-Neto and Kellner 1988). The record uncovered an asymmetrical feather typical of modern avian primary remiges (Martins-Neto and Kellner 1988, Kellner et al. 1991, Naish et al. 2007). Three other asymmetrical feathers found in association with bone fragments were preliminary described (Naish et al. 2007). With regards to symmetrical feathers, two small semiplumes were reported (Martill and Filgueira 1994) in addition to a very small and fluffy down feather (Kellner et al. 1994). Such feathers occur frequently in the Crato Formation, with about 20 specimens presented and described in the literature (Naish et al. 2007). Also, two contour feathers were described in the presence of alternate dark and light bands, one incomplete (Martill and Frey 1995, Vinther et al. 2008, 2010) and one complete (Kellner and Campos 2000, Kellner 2002).

\section{GEOLOGICAL SETTING}

The Araripe Basin contains Cretaceous sediments, deposited during the opening of the South Atlantic Ocean and is associated with lacustrine and transitional marine sediments (Valença et al. 2003, Fara et al. 2005). The stratigraphy and the temporal range of the basin are controversial (Small 1913, Ponte and Appi 1990, Martill and Wilby 1993, Neumann and Cabrera 1999, Valença et al. 2003, Martill 2007a, b, Assine 2007).
The age of the shales has been estimated as Aptian (Brito 1984, Wellnhofer 1985, 1991), Aptian/Albian (Arai et al. 2000), Albian (Campos and Wenz 1982, Berthou 1990), possibly Cenomanian (Martill and Wilby 1993), and Turonian (Beurlen 1962). This divergence in age estimates is therefore up to 30 million years (Martill 2007b), creating a controversial time chart. In this study we followed the stratigraphy of Valença et al. (2003) in order to resolve questions surrounding the Basin's nomenclatural.

The Crato Formation is positioned at the bottom of the Santana Group. It comprises an area with nearly $5,500 \mathrm{~km}^{2}$, bounded by the cities of Santana do Cariri to Bonito de Santa Fé (E-W oriented) and Nova Olinda to Jati (N-S oriented) (Viana and Neumann 2002). Its outcrop pattern forms a narrow strip along the flanks of the plateau, and is also present as a few isolated outliers to the south of the plateau (Martill 1993, Neumann and Cabrera 1999, Valença et al. 2003, Martill 2007a, b). This unit is composed of alternating darkcolored, calciferous shale laminae and grey colored micritic limestone laminae with variable clay content (Mabesoone and Tinoco 1973, Valença et al. 2003). This complex is interpreted as a lacustrine paleoenvironment with strong seasonal cycles under fairly dry climatic circumstances, with their marginal and distal areas distinguished through analyzing differences in facies architecture (Valença et al. 2003). Its base is defined by the first appearance of laminated limestones and its top by the first appearance of the evaporites of the overlying Ipubi Formation (Neumann and Cabrera 1999, Valença et al. 2003, Martill 2007a, b). The age of the Crato Formation is considered as late Aptian, according to ostracods (Berthou et al. 1994) and palynomorphs (Pons et al. 1990, Coimbra et al. 2002, Batten 2007), although some palynological data suggest that it might be early Albian (Lima 1978, 1980, Hashimotto et al. 1987).

The preservation of the fossils is often exquisite, earning to the Crato Formation its status as a Konservat Lagerstätte (Martill and Frey 1998, Kellner and Campos 1999, Sayão and Kellner 2000, Martill 2007a, b). Most of the fossils described from the limestones was collected by local workers and, consequently, many lack detailed stratigraphic information. Abundant fossil in- 
sects occur in the laminated deposits, belonging to at least 21 orders and 10 families (Martins-Neto 2001). In addition, ostracods, conchostracans (Carvalho and Viana 1993), fishes (e.g. Santos 1947, Castro-Leal and Brito 2004), amphibians (Kellner and Campos 1986, CastroLeal and Brito 2006, Castro-Leal et al. 2007, Baez et al. 2009), pterosaurs (Frey and Martill 1994, Campos and Kellner 1997, Sayão and Kellner 1998, 2000, 2006, Frey et al. 2003, Witton 2008) and crocodylomorphs (Salisbury et al. 2003, Figueiredo and Kellner 2009), as well as a rich flora of pollen, spores and plant fragments, are present. Lastly, several feathers have been collected and described (Martins-Neto and Kellner 1988, Kellner et al. 1991, 1994, Martill and Filgueira 1994, Martill and Davis 1998, 2001, Kellner 2002), some of which even show the presence of colored patterns (Martill and Frey 1995, Kellner et al. 1999, Naish et al. 2007, Vinther et al. 2008, 2010).

\section{MATERIALS AND METHODS}

The two specimens were collected during the field season of 2009 by biology students of the Centro Acadêmico de Vitória (Universidade Federal de Pernambuco). Both feathers are deposited in the Paleontological collection of the same institution under the numbers CAV 0001-V and CAV 0002-V. They were found in the renowned limestone mine, Mina do Demar, on the road that connects the cities of Nova Olinda and Santana do Cariri (Fig. 1). Both specimens were described, measured and photographed under a stereomicroscope linked to a digital system.

\section{INSTITUTIONAL ABBREVIATIONS}

CAV - Centro Acadêmico de Vitória, Universidade Federal de Pernambuco.

GP - Coleção de Geologia e Paleontologia, Universidade de São Paulo.

LEIUG - Leicester University, Geology Department.

MCT - Museu de Ciências da Terra.

MPSC - Museu de Paleontologia de Santana do Cariri.

\section{RESULTS}

The first new feather (CAV 0001-V) is $18.81 \mathrm{~mm}$ long without the calamus (not preserved), and $13.66 \mathrm{~mm}$ wide.
A short rachis is preserved $(5.07 \mathrm{~mm})$ corresponding to less than $27 \%$ of its total length. It is also shorter than the barbs with the bigger barb having $11.85 \mathrm{~mm}$, and the smaller $5.4 \mathrm{~mm}$. The barbs are closely connected, creating a fluffy texture (Fig. 2). All present high ramifications in two rolls of barbules. These are more numerous on the basis of the barb and decreases in number and size distally.

CAV 0001-V represents a complete down feather by having the rachis shorter than the longest barb (Lucas and Stettenheim 1972). This kind of fluffy feather composes the under plumage of the body and its major function in the tegument is insulation. Despite other down feathers from the same locality being found (Naish et al. 2007), only one was described in detail: the $7.5 \mathrm{~mm}$ long MCT 1493-R (Kellner et al. 1994). According to Naish et al. (2007) this kind of feather ranges from 10-20mm. MCT 1493-R, however, is outside this estimation. Conversely, CAV 0001-V was found closest to the longest down feathers known in these deposits. Despite the large size disparity between MCT 1493-R and CAV 0001-V (more than twice), they are very similar in morphology.

The smaller feather (CAV 0002-V) has a dark brown color, which contrasts against the light yellow limestone (Fig. 3). It shows a staining variation, with the base of the calamus darker and being lighter closer to the rachis. A very light band pattern was observed on the border (distally) of the barbs, interposing between the light and dark shades. It differs from the color-banded feathers described before, which have the bands essentially perpendicular to the rachis (Martill and Frey 1995, Kellner 2002, Vinther et al. 2010). In many extant birds the distal barbules that cover the outer surface of the pennaceous feather vanes are more heavily pigmented than the proximal barbules (e.g. Strong 1902), as observed in CAV 0002-V. This detailed patterning in pigmentation requires mechanisms that distinguish between distal and proximal barbule plate cells that are separated only by a single layer of axial plate cells (Prum and Dyck 2003).

The length of the preserved specimen is $8.55 \mathrm{~mm}$, with the calamus having $0.47 \mathrm{~mm}$, and being displaced from the original position probably during fossilization. The rachis is very thin and proportionately long (4.76 mm), corresponding to more than $55 \%$ of the 

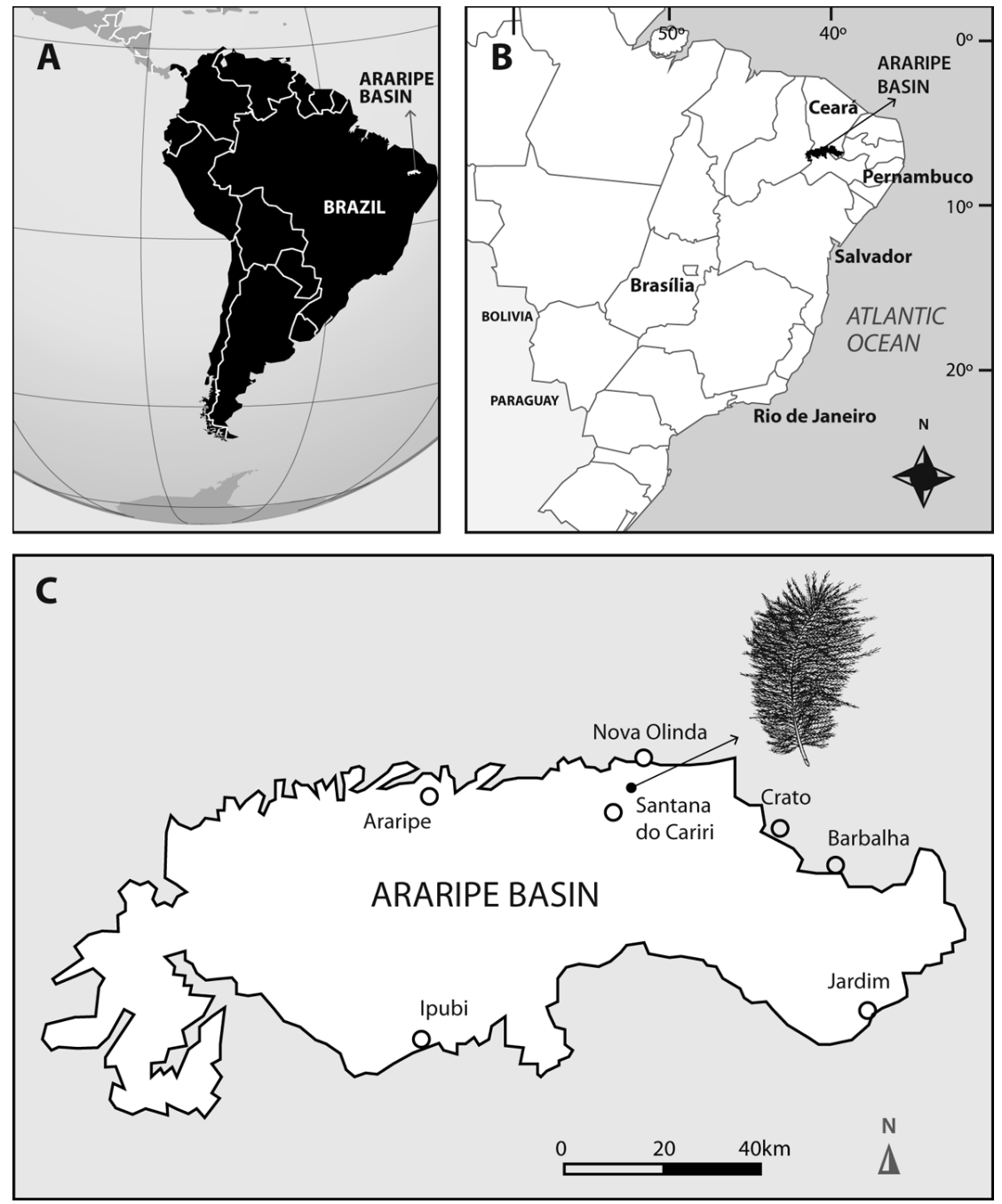

Fig. 1 - A. Location of the Araripe Basin in South America. B. The Araripe Basin bordering the states of Ceará, Piauí and Pernambuco in northeast Brazil. C. Outline map of the Araripe Basin, indicating the site of the mine where the new feathers were found, between the cities of Nova Olinda and Santana do Cariri (Ceará State).
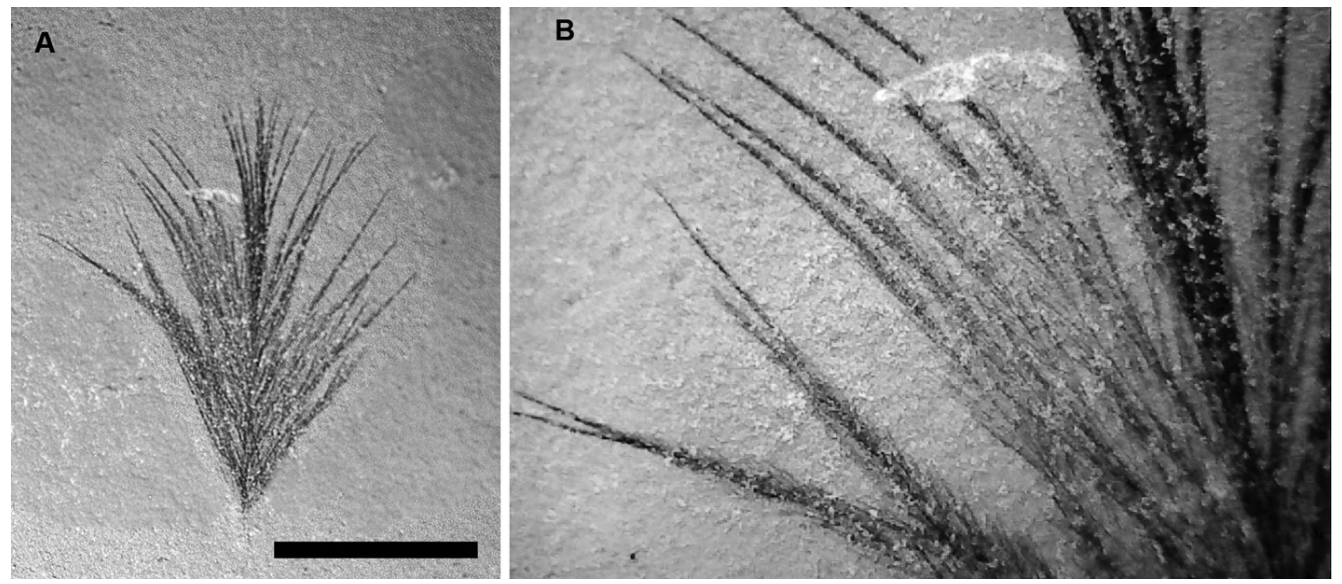

Fig. 2 - A: Fossil down feather CAV 0001-V. B: Detail of the barbs and barbules. Scale Bar 9 mm in A, B not in scale. 

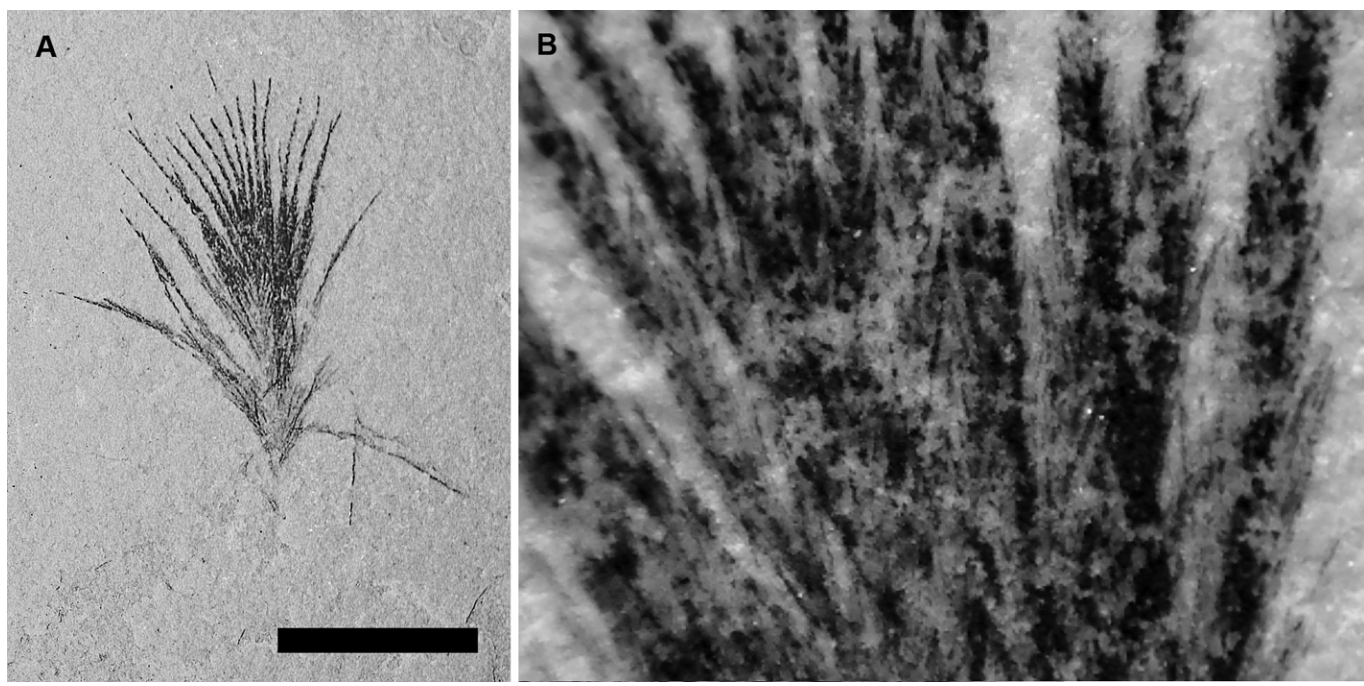

Fig. 3 - A: Semiplume CAV 0002-V. B: Detail of the barbs and barbules in the distal region of the feather. Scale Bar $5 \mathrm{~mm}$ in A, B not in scale.

total preserved length of the feather. It is also longer than the larger barb $(4.71 \mathrm{~mm})$. Due to this proportion, CAV 0002-V represents a semiplume (according to Lucas and Stettenheim 1972). This type of feather has a large rachis and entirely plumaceous vanes, which places this kind of structure as an intermediate between a contour and a down feather. Functionally, semiplumes fill out the contour of the animal body (Fig. 4) and also provide thermal insulation (Hudon 2005).

The size of individual barbs decreases towards the distal portion of the shaft. The last and smallest barb on the terminal portion of the shaft is $3.34 \mathrm{~mm}$. It differs from a previously described semiplume (LEIUG $114369)$, which has long shaft $(21 \mathrm{~mm})$ and comparatively short barb (longest barbs 8-10 mm - Martill and Filgueira 1994). In this record, the shaft represents more than twice the length of the barbs, while in CAV $0002-\mathrm{V}$ this ratio is less than twice. On each side of the barbs there is a row of smaller branches, the barbules. They are visible on a number of barbs with both proximal and distal barbules being identifiable. No hookletlike structures were observed. To date, CAV 0002-V is the smallest semiplume described for these deposits.

During this work a new feather was found in the same locality as CAV 0001-V and CAV 0002-V. It is currently located in the fossil collection of Museu de Paleontologia de Santana do Cariri, under collection number
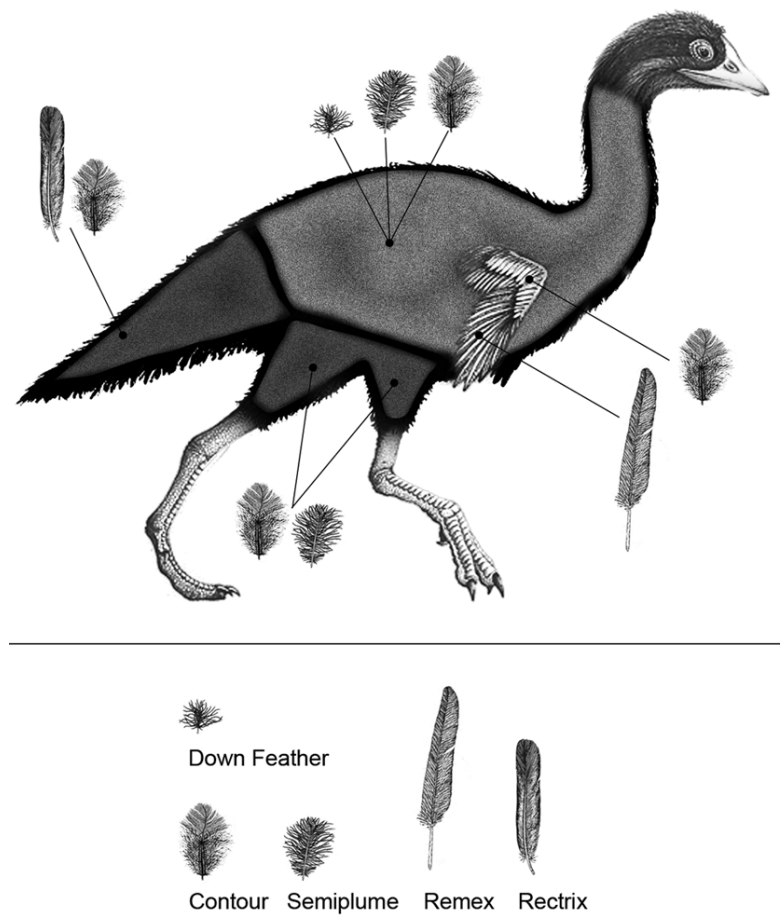

Fig. 4 - Sketch of a hypothetical flightless animal showing the distribution of the different feather types in the body.

MPSC - PN 2221. It possesses a different morphology from all other feathers found in the Crato Formation, with long calamus and rachis. Filamentous, long and free barbs lacking barbules inserted opposite to each other on 
each side of a rather flattened rachis and form two vanes (Fig. 5). It is very similar in morphology to feathers preserved in amber from the Early Cretaceous in France (Perrichot et al. 2008). This feather is morphologically similar to the down or ornamental ones, and not to the contour, remiges or rectrices. However, it has a thick and long rachis, unlike classical down feathers whose barbs generally diverge from the very short apex of the rachis.

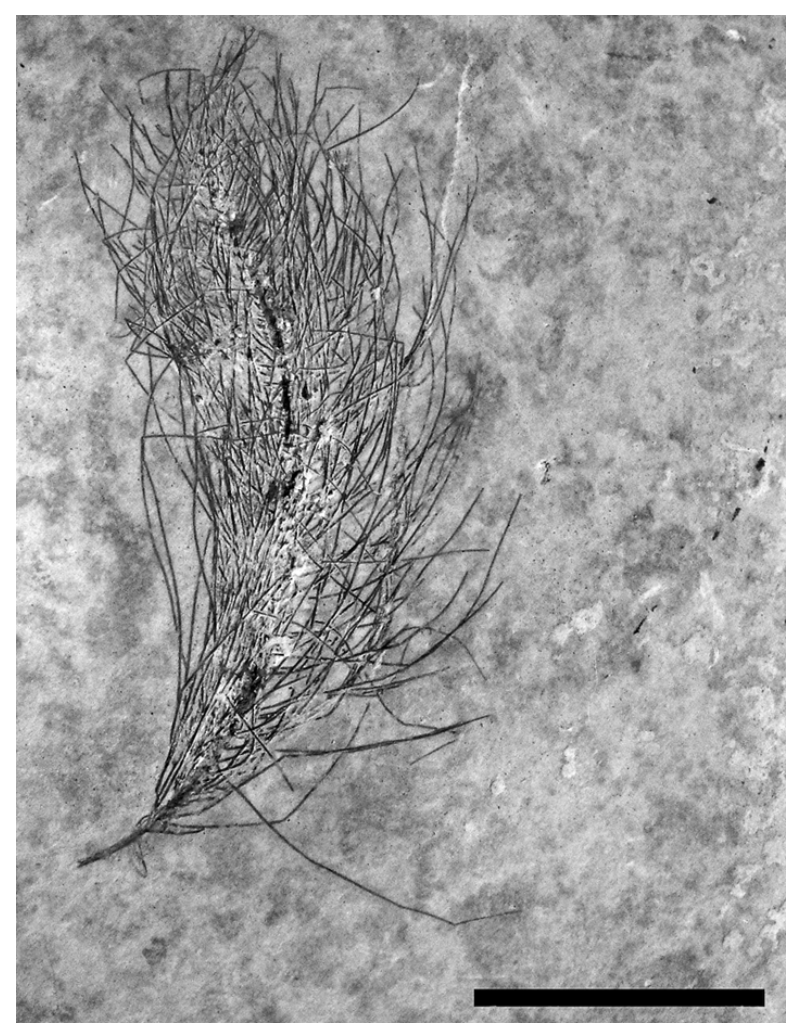

Fig. 5 - Fossil feather from Museu de Paleontologia de Santana do Cariri (MPSC - PN 2221), without barbules. Scale Bar 25 mm.

\section{DISCUSSION}

The preservation of such delicate structures as feathers is very rare in the paleontological record, due to the fragility of their components. Despite this, in $77 \%$ of sediments yielding fossil feathers, they are the only evidence of an avian presence, whereas bones are absent (Davis and Briggs 1995). For a long time, feathers were diagnostic of the Aves class. They helped to identify Archaeopteryx from the Tithonian (Upper Jurassic) Solnhofen Limestone as the earliest known bird, rather than as a birdlike dinosaur (Rietschel 1985). In the last decade feathers or primitive feathers have been documented in non-avian coelurosaurian theropod groups, on the basis of numerous specimens recovered from the Lower Cretaceous Jehol Group and the Jurassic Daohugou or Tiaojishan Formations in China (Xu et al. 2010). The presence of feathers in the Crato Formation was, up to now, used to point towards the existence of Aves in these deposits. New data can now be used to reappraise this hypothesis.

According to Lucas and Stettenheim (1972), feathers are generally divided in the two main categories: symmetrical and asymmetrical. Despite the fact that the symmetrical type corresponds to the majority of feathers in the Crato Formation, only a few were formally described. Two or three possible rectrices have been mentioned in the literature (Naish et al. 2007). One of these (NSM PV20059) is the longest feather known from this unit (Martill and Davis 1998, 2001). The symmetrical feathers from the Crato Formation are two contour feathers (Martill and Frey 1995, Kellner 2002) and two semi plumes (LEIUG 114369; CAV 0002-V). The most common type are down feathers, such as CAV 0001-V.

Normally the body feathers account for more than half of a bird's feather mass (Debruyne et al. 2006). Also, bird carcasses usually disarticulate quickly after death. According to Davis and Briggs' (1995) analysis, a $10 \%$ reduction in body mass may be expected after 30 days in subtropical or shallow marine environments, in addition to the loss of contour features of the body. The ligaments that attach the wing contour feathers to the ulna are decay resistant, and the wing may remain intact even after disarticulation of the rest of the skeleton.

Another aspect is that feathers are sequentially replaced throughout the life of the bird through periodic molting (Prum and Dick 2003). Molting is the renewal of an entire plumage through the growth of serially homologous replacement feathers (Howell et al. 2003, Prum and Dyck 2003, Rohwer 2008), whereby old feathers are pushed out and lost as new feathers are generated from the same feather follicle (Rohwer and Wang 2010). In extant birds, feathers are usually molted once a year, often twice a year, and occasionally once every other year (Prum 1999, Prum and Dyck 2003). The molt 
process is regulated by a combination of hormonal and environmental factors, such as temperature and photoperiodism (Lindström et al. 1994, Hahn et al. 2009). This process interferes in fundamental biological activities, such as reproduction and flight, resulting in a high energetic cost (Lindström et al 1994). In this period, the hormonal regulation is not restricted to control the timing of the molt, but also the sequence of changes in the body and the amount of feathers lost (Ellis et al. 2006, Rohwer et al. 2009). During the normal molt the functional continuity and integrity of the plumage is maintained during the process of complete or partial plumage replacement (Prum and Dyck 2003, Rohwer 2008). In that way the maintenance of flight function during molt requires the sequential replacement of remiges and rectrices without compromising the function of the entire airfoil. Different groups of birds have evolved different feather replacement sequences (Stresseman and Stresseman 1966). Remiges and rectices have a lower occurrence in the body of an individual yet these feathers have a large mass and length (Ellis et al. 2006), requiring more time and energy during their transformation, than other feathers do, such as down, semiplume and contour ones (Rohwer 2008, Rohwer et al. 2009). In most extant birds, flight feathers change a few units at a time, for example two or three primary remiges in each wing (Rohwer et al. 2009). Meanwhile the turnover of covert feathers is high since they are numerous and significantly smaller, changing without a certain number or specific body part (Ellis et al. 2006). Consequently, the time of such molt is significantly lower than the flight molt (Munro et al. 2006). Because flight feather molting is of fundamental importance to many aspects of avian biology (Rohwer 2008), it is easier to find molted feathers of the body (such as contour, semiplume and down feathers) than remiges and rectrices. The difference in number, molt duration and quantity of changed feathers could be related to the large amount of covert feathers in the fossil record of the Crato Formation, besides taphonomic aspects.

Until now only one asymmetrical feather has been reported (GP/2T-136), curiously the first one described (Martins-Neto and Kellner 1988). It was a $64 \mathrm{~mm}$ long typical primary remex with no evidence of barbules
(Martins-Neto and Kellner 1988). Remiges are located on the posterior side of the wing whereupon the barbules are ended by hooks, which help to stiffen the flight feathers of the birds. The only exception is the remiges of ratites, which are soft, lacking the interlocking hooks and barbules (Speer 2006). The presence of a remex in the Crato Formation suggests the presence of a flying bird in these deposits. This was reinforced by the supposed presence of an enantiornithine bird (Naish et al. 2007), a flying, cosmopolitan group recorded throughout the Cretaceous (Chiappe and Walker 2002). The evidence, however, was based on a lowresolution photograph and a brief description (Naish et al. 2007). Furthermore, some non-avian theropods present asymmetrical vaned feathers such as Microraptor gui (Zhou 2004). In this species the flight capability is not fully accepted, leading to the conclusion that asymmetrical feathers were developed initially for some more primeval stage of flight (Zhou 2004). Because the specimens in Senckenberg Museum and the Japanese private collection (both of which have three remiges associated with bones) have yet to been described (see Naish et al. 2007 for a review), no formal evidence of a flying bird can be confirmed. The primary remex (GP/2T-136) could be associated to a flightless individual due to its similarity with the one of the flightless birds. Flight has been lost independently numerous times in at least 34 families of birds, including both extant and extinct forms (Livezey 1995, Middleton and Gatesy 2000). In the Late Cretaceous several groups of fossil birds lost the ability to fly, such as one of the earliest secondarily flightless birds, Patagopteryx deferrariisi from southern Argentina (Alvarenga and Bonaparte 1992, Chiappe 1995, 2002). Despite being initially referred to as a ratite (Alvarenga and Bonaparte 1992), posterior analyses placed the species between the enantiornithine radiation, and the divergence of another major group, Ornithurae, which contains the most immediate outgroups of extant birds (Padian and Chiappe 1998, Chiappe 2001, 2002, Chiappe and Dyke 2002). The absence of structures considered specialized for flight in the feather GP/2T-136 suggests that maybe this feather comes from a flightless bird, also in the Lower Cretaceous Crato Formation. 
The major question regarding fossil feathers from the Araripe Basin is to define from which animal they belonged to. Generally the dimensions of a feather (length, width, calamus length, downy part, aftershaft length) as well as its curvature (including lateral curvature) can assist species identification or origin, particularly in birds (Hudon 2005). The outer surface of such a structure can always be recognized by the smooth side of the shaft, which faces away from the body except in certain coverts on the underside of the wings. One of the most distinctive features of a feather is its coloration and patterning. However this characteristic is of little use when the feather is white or in decay, as is the case in fossilized specimens. Previous work associated these structures to the presence of Aves in the deposits (Martins-Neto and Kellner 1988, Kellner et al. 1991, Martill and Filgueira 1994). However when this was proposed, feathers were considered exclusive of birds, making this association incorrect in the face of new findings.

The existence of a suite of differentiated and structurally modern feather types (e.g., primary and secondary, remiges, retrices, and covertors) in Archaeopteryx strongly suggests that the origin of feathers predated the origin of birds (Sereno 1999, Rayner 2001). This prediction has been confirmed by a number of discoveries from the lacustrine Early Cretaceous deposits of Liaoning Province (China), including at least eight taxa of non-avian theropod dinosaurs. These specimens preserve integumentary structures that were interpreted as feather homologes (Chen et al. 1998, Ji et al. 1998, Xu et al. 1999a, b, 2000, 2001, 2003, 2009, Norell et al. 2002, Zhou et al. 2003). It is notable that integumentary structures in these dinosaurs can be broadly classified into two categories: one mostly fiber-like and unbranched, and the other consisting of unambiguous true feather structures (Zhou 2004, Xu et al. 2009). Varying greatly in morphology and size, these new taxa represent lineages phylogenetically spread throughout the non-avian coelurosaurian portion of the theropod tree (Chiappe and Dyke 2002, Currie 2003, Xu et al. 2003, 2009, 2010, Zhou, 2004). They show evidence for at least two groups of coelurosaurs that have feathers preserved with the diagnostic features of shafts and barbs. In most cases these modern feathers are distributed in both the forelimb, tail region and hindlimb of the Microraptor gui (see Zhou 2004 for a review). Accordingly, this may indicate that modern feathers are present and common in coelurosaurids, including dromaeosaurids (e.g. Sinornithosaurus, Microraptor), oviraptorosaurids (Caudipteryx), and the poorly known coelurosaur, Protarchaeopteryx (Zhou 2004). The presence of feathers with shaft, barbs and asymmetry was known previously only in volant birds. Recently it was demonstrated that the attachments of the forelimb feathers in these dinosaurs are consistent with those of modern birds (Xu et al. 2003). Thus, asymmetry is also of no help in the systematic interpretations of isolated feathers. Worse still, there are no confirmed records of birds and other feathered archosaurs in the region to date.

Developmental theories propose that feathers evolved through a series of evolutionary novelties in the developmental mechanism of the follicle and feather germ (Dyck 1985, Prum 1999, Chuong et al. 2000, Prum and Williamson 2001, Prum and Brush 2002, Perrichot et al. 2008, Xu et al. 2010). In this model, feathers were divided originally into five morphotypes (Prum 1999), refined in subsequent works to nine (Perrichot et al. 2008, Xu et al. 2010). Feathers from the Crato Formation belong to morphotypes II, III, and probably V. The morphotype II resembles to a tuft of unbranched barbs with a basal calamus (Prum 1999), very similar to MPSC-PN 2221. This morphology, with a rachis forming a kind of primitive vanes without barbules, is entirely consistent with the shafted displayed by the dromeosaur Sinornithosaurus (Ji et al. 2001, Xu et al. 2001). All the semi-plumes and the downs are framed in the morphotype III (according to Prum 1999). In that morphotype, paired barbules within the peripheral barbule plates of the barb ridges, created the branched barbs with rami and barbules. This is considered the most critical stage of a feathers evolution in birds or non-avian dinosaurs since it is present in both (Xu 2006, Perrichot et al. 2008). The GP/2T-136 specimen does not fit in any of the known morphotypes. Because of its asymmetry it could be placed within the morphotype $\mathrm{V}$, but it differs from this morphotype in the absence of barbules. To date, this type of feather was considered unique to birds (Prum and Brush 2002), is now recognized to have 
a more ancient origin, among non-avian dinosaurs. As mentioned above, it has also been found in Microraptor and other dromeosaurs (Norell et al. 2002).

\section{CONCLUSIONS}

The new feathers presented in this study differ between themselves and others found in the Crato Formation, in terms of color, pattern, shape and size. The great range in feather size from this locality does not necessarily mean a variety of animal sizes. In most birds, the shape of each feather is established during its growth and does not change thereafter except through wear. Feathers may change in appearance as they are replaced as a function of their age, gender, and the seasonal changes of the bird. Since there is no confirmed evidence of feathers preserved with bones, it is difficult to associate the differences to any of the aspects in a way that could explain this variation. The central objective regarding fossil feathers from the Araripe Basin is to identify from which animal they came. Feathers from the Crato Formation belong mostly to morphotype III, which is the most common shape found in both non-avian and avian theropods (from Tyrannosauroidea to Enantiornithes). However, the record of an asymmetrical feather without barbules and hooks hints at the presence of a flightless animal in this deposit, which could be either a bird or a nonavian theropod. If the bird origin for this feathers is confirmed, this would consitute the earliest avian remain in South America. However, the presence of a feather from morphotype II (present in Tyrannosauroidea, Compsognathidae, Therizinosauroidea and Dromeosauridae) introduces the possibility of a non-avian theropod origin. Since there are no confirmed reports of birds and other feathered archosaurs in the region to date, more evidence is needed to elucidate the true origin of the feathers.

\section{ACKNOWLEDGMENTS}

We would like to dedicate this paper to the late Rafael Gioia Martins Neto who started the feather studies in the Araripe Region. Alexander W.A. Kellner (Museu Nacional/UFRJ) for the opportunity to join the volume. The Paleontology class of 2009, especially Laiz Karla for collecting the specimens. Taissa Rodrigues (Museu Nacional/UFRJ) and Bruno Vila Nova (Universidade de São Paulo) kindly helped with the text. Matheus Bar- bosa for Figures 2 and 4. Pro-Reitoria de Assuntos Acadêmicos (PROACAD/UFPE) for the financial support for field classes. Finally, the two anonymous reviewers for comments that improved the paper.

\section{RESUMO}

A fossilização de estruturas de revestimento delicadas como as penas constitui um processo extremamente raro, principalmente pela fragilidade de seus componentes. São conhecidos apenas cinquenta depósitos com esta natureza de registro (do Jurássico ao Terciário). No Brasil a primeira referência data de 1916, descrevendo uma pena de vôo com características plumáceas da Formação Tremembé (Bacia de Taubaté). Outras evidências, são provenientes dos calcários laminados da Formação Crato, apresentando registros de penas assimétricas e apenas uma simétrica. Com base em novos achados e reavaliando penas previamente descritas, verificou-se que não se pode afirmar a presença de Aves voadoras nestes depósitos. Isto se deve a ausência de estruturas exclusivas deste tipo de hábito, a exemplo de penas assimétricas com bárbulas e ganchos. Ao contrário disso, verificou-se que os registros apontam mais para a presença de animais emplumados não voadores, como terópodes não avianos ou Aves que tenham perdido secundariamente o voo. Reforçando esta ideia está a presença de uma pena pertencente ao morfótipo do estágio II encontrado até o momento em Tyrannosauroidea, Compsognathidae, Therizinosauroidea e Dromeosauridae. A ausência de registros confirmados de aves ou de outros arcossauros emplumados na região até o momento, geram expectativas sobre novos registros que apontem para os organismos detentores das penas encontradas neste depósito.

Palavras-chave: Bacia do Araripe, Formação Crato, Cretáceo, penas, teropoda.

\section{REFERENCES}

ACKermann FL. 1964. Geologia e fisiografia da Região Bragantina (Estado do Pará). Cadernos da Amazônia (INPA) 2: $1-90$.

Alvarenga HMF. 1988. Ave Fossil (Gruiformes: Rallidae) dos Folhelhos da Bacia de Taubaté, Estado de São Paulo, Brasil. An Acad Bras Cienc 60(3): 321-328.

Alvarenga HMF And Bonaparte JF. 1992. A new flightless landbird from the Cretaceous of Patagonia. In: CAmpbell KE (Ed), Papers in Avian Paleontology Honoring Pierce Brodkorb, Science Series, Nat Hist Mus Los Ang City 36: 51-64. 
Arai M, Neto JB, Lana CC and Pedrao E. 2000. Cretaceous dinoflagellate provincialism in Brazilian marginal basins. Cretaceous Res 21: 351-366.

Assine ML. 2007. Bacia do Araripe. In: Boletim de Geociências. Petrobras, Rio de Janeiro 15(2): 371-389.

Baez AM, Moura GJB And Batten RG. 2009. Anurans from the Lower Cretaceous Crato Formation of northeastern Brazil: implications for the early divergence of neobatrachians. Cretaceous Res 30: 829-846.

BATTEN DJ. 2007. Spores and pollen from the Crato Formation: biostratigraphic and palaeoenvironmental implications. In: MARTILl DM ET AL. (Eds), The Crato Fossil Beds of Brazil: Window into an Ancient World, Cambridge University Press, p. 566-573.

Bereiter-Hahn J, Matoltsy AG AND Richards KS. 1986. Biology of the Integument, Vol. 2, Vertebrates. Springer-Verlag, Berlin and New York, $856 \mathrm{p}$.

BERTHOU PY. 1990. Le basin d'Araripe et les petits bassins intracontinentaux voisins (NE du Bresil): formation et evolution dans le cadre de l'overture de l'Atlantique equatorial. Comparison avec les bassins ouest-africanis situes dans le meme contexte. In: CAMPOS DA, VIANA MSS, Brito PM And Beurlen G (Eds), Atas do Simpósio Sobre a Bacia do Araripe e Bacias Interiores do Nordeste, Crato, p. 113-134.

Berthou Py, Depeche F, Colin JP, Filgueira JBM AND TELES MSL. 1994. New data on the ostracods from Crato lithologic units (lower member of the Santana Formation, Latest Aptian-Lower Albian) of the Araripe Basin (Northeastern Brazil). Acta Geol Leopol 39(2): 539-554.

Beurlen K. 1962. Geologia da Chapada do Araripe. An Acad Bras Cienc 34: 365-370.

BRITO IM. 1984. The upper Lower Cretaceous in Brazil, its divisions and boundaries. An Acad Bras Cienc 56: 287293.

Buffetaut E, Jurkovsek B AND Kolar-JurkovseK T. 2002. A fossil feather from the Upper Cretaceous of Kras (Slovenia). CR Palevol 1: 705-710.

CAmpos DA And Kellner AWA. 1997. A short note on the first occurence of Tapejaridae in the Crato Member (Aptian), Santana Formation, Araripe basin, Northeast Brazil. An Acad Bras Cienc 69(1): 83-87.

Campos DA And Wenz S. 1982. Premiere découverte de coelacanthes dans le Crétace infériur de la Chapada do Araripe (Brésil). CR Palevol 294: 1151-1154.

CARVAlho IS AND VIANA MSS. 1993. Os conchostráceos da Bacia do Araripe. An Acad Bras Cienc 65(2): 181-188.
CAstro-Leal ME AND BRito PM. 2004. The ichthyodectiform Cladocyclus gardneri (Actinopterygii: Teleostei) from the Crato and Santana formations, Lower Cretaceous of Araripe Basin, north-eastern Brazil. Ann Palaontol 90: 103-113.

Castro-Leal ME and Brito PM. 2006. Anura do Cretáceo Inferior da Bacia do Araripe, Nordeste do Brasil. In: Gallo V ET AL. (Eds), Paleontologia de Vertebrados grandes temas e contribuições científicas, Rio de Janeiro, Interciência, p. 145-152.

Castro-Leal ME, Martill DM and Brito PM. 2007. Anurans of the Crato Formation. In: MARTILL DM ET AL. (Eds), The Crato Fossil Beds of Brazil, Window into an Ancient World, Cambridge University Press, p. 444451.

CHEN PJ, Dong ZM AND ZHEN SN. 1998. An exceptionally well-preserved theropod dinosaur from the Yixian Formation of China. Nature 391: 147-152.

ChiAppe LM. 1995. The phylogenetic position of the Cretaceous birds of Argentina: Enantiornithes and Patagopteryx deferrariisi. CFS 181: 55-63.

ChIAPPE LM. 2001. Phylogenetic relationships among basal birds. In: Gauthier J And Gall LF (Eds), New perspectives on the origin and early evolution of birds, Special Publication of the Peabody Museum of Natural History, Yale University, New Haven, p. 125-139.

ChIAPPE LM. 2002. Osteology of the flightless Patagopteryx deferrariisi from the Late Cretaceous of Patagonia. In: Chiappe LM AND WitMer L (Eds), Mesozoic Birds: Above the Heads of Dinosaurs, University of California Press, p. 281-316.

ChIAPpe LM AND Dyke GJ. 2002. The Mesozoic radiation of birds. Ann Rev Ecol Sys 33: 91-124.

ChIAPPE LM AND WALKER CA. 2002. Skeletal morphology and systematics of the Cretaceous euenantiornithes (Ornithothoraces: Enantiornithes). In: CHIAPPE LM AND WitMer LM (Eds), Mesozoic birds above the heads of dinosaurs, University of California Press, Berkeley, California, USA, p. 240-267.

Chuong CM, Chodankar R, Widelitz RB AND JiAng TX. 2000. Evo-devo of feathers and scales: building complex epithelial appendages. Curr Opin Genet Dev 10: $449-456$.

Coimbra JC, Arai M And Carreno AL. 2002. Biostratigraphy of Lower Cretaceous microfossils from the Araripe Basin, northeastern Brazil. Geobios 35: 687-698.

CURRIE PJ. 2003. Feathered dinosaurs and the origin of birds. In: LEGAKIS A ET AL. (Eds), The new panorama 
of animal evolution, Proceedings of the $18^{\text {th }}$ International Congress of Zoology, p. 55-60.

DAVIS PG AND BRIGGS DEG. 1995. Fossilization of feathers. Geology 23(9): 783-786.

Debruyne CA, Hughes JM And Hussel DJT. 2006. Age-related timing and patterns of prebasic body molt in wood warbles (Parulidae). Wilson Bull 118(3): 374379.

DYCK J. 1985. The evolution of feathers. Zool Scr 14: 137154.

Ellis DH, Lish JW, KeRY M AND RedPATH SM. 2006. Short-term oscilations in avian molt intensity: evidence from the golden eagle Aquila chrysaetos. J Avian Biol 37: 642-644.

Fara E, SARaiva AAF, Campos DA, Moreira JKR, Carvalho Siebra D and Kellner AWA. 2005. Controlled excavation in the Romualdo Member of the Santana Formation (early Cretaceous, Araripe Basin, northeast Brazil): stratigraphic, palaeoenvironmental and palaeoecological implications. Palaeogeogr Palaeoclimatol Palaeoecol 218: 145-160.

Figueiredo RG AND Kellner AWA. 2009. A new crocodylomorph specimen from the Araripe Basin (Crato Member, Santana Formation), northeastern Brazil. Paläontol Z 83: 323-331.

Frey E AND MARTILl DM. 1994. A new pterosaur from the Crato Formation (Lower Cretaceous, Aptian) of Brazil. N Jb Geol Paläont Abh 194: 379-412.

Frey E, Martill DM AND Buchy MC. 2003. A new crested ornithocheirid from the Lower Cretaceous of northeastern Brazil and the unusual death of an unusual pterosaur. In: BuffetAut E AND MAZIN JM (Eds), Evolution and Palaeobiology of Pterosaurs. Geol Soc, London, Spec Pub 217: 55-63.

HAHN TP, WATTS HE, CORNELIUS JM, BRAZEAL KR AND MacDougall-SHACKLETON SA. 2009. Evolution of environmental cue response mechanisms: Adaptive variation in photorefractoriness. Gen Comp Endocrinol 163(12): 193-200.

Hashimotto AT, Appi CJ, Soldan AL ANd CERQUeira JR. 1987. O neo-Alagoas nas Bacias do Ceará, Araripe e Potiguar (Brasil): caracterização estratigráfica e paleoambiental. RBG 17(2): 118-122.

Howell SNG, Corben C, Pyle P ANd Rogers DI. 2003. The first basic problem: A review of molt and plumage homologies. Condor 105: 635-653.

Hudon J. 2005. Considerations in the conservation of feathers and hair, particularly their pigments. In: CANADIAN
Association for Conservation, $31^{\text {st }}$ Annual Conference, Fur Trade Legacy Workshop, Jasper, Canada, p. 127-147.

Ji Q, Currie PJ, Norell MA ANd Ji SA. 1998. Two feathered dinosaurs from northeastern China. Nature 393: 753-761.

Ji Q, Norell MA, Gao KQ, Ji SA AND Ren D. 2001. The distribution of integumentary structures in a feathered dinosaur. Nature 410: 1084-1088.

KELLner AWA. 2002. A review of avian Mesozoic fossil feathers. In: CHIAPPE LM AND WiTMER LM (Eds), Mesozoic Birds: above the head of dinosaurs, University of California Press, Berkeley, USA, p. 389-404.

Kellner AWA And CAmpos DA. 1986. Primeiro registro de Amphibia (Anuro) no Cretáceo Inferior da Bacia do Araripe, Nordeste do Brasil. An Acad Bras Cienc 58 (4): 610.

Kellner AWA AND CAmpos DA. 1999. Vertebrate paleontology in Brazil - a review. Episodes 22(3): 238-251.

Kellner AWA AND CAMPos DA. 2000. Brief Review of Dinosaur Studies and Perspectives in Brazil. An Acad Bras Cienc 72(4): 509-538.

Kellner AWA, Maisey JG And Campos DA. 1994. Fossil down feather from lower Cretaceous of Brazil. Paleontology 37(3): 489-492.

Kellner AWA, Martins-Neto RG And Maisey JG. 1991. Undeterminated feather. In: MAISEY JG (Ed), Santana Fossils, an illustred atlas, TFH Publications, Neptune City, p. 376-377.

LIMA MR. 1978. Palinologia da Formação Santana (Cretáceo do Nordeste do Brasil). Tese de Doutoramento. Universidade de São Paulo, 335 p.

Lima MR. 1980. Palinologia da Formação Santana (Cretáceo do nordeste do Brasil). III. Descrição sistemática dos polens da turma Plicates (Subturma Costates). Ameghiniana, 17: 15-47.

Lindström A, DAAN S AND Visser H. 1994. The conflict between moult and migratory fat deposition: a photoperiodic experiment with bluethroats. Anim Behav 48: 1173-1181.

LIVEZEY BC. 1995. Heterochrony and the evolution of avian flightlessness. In: MCNAMARA KJ (Ed), Evolutionary Change and Heterochrony. J Wiley \& Sons Ltd, p. 169193.

LuCAs AM And Stettenheim PR. 1972. Avian anatomy integument (parts 1 and 2). Agriculture Handbook 362: $1-750$.

Mabesoone JM And Tinoco IM. 1973. Palaeoecology 
of the Aptian Santana Formation (northeastern Brazil). Palaeogeogr Palaeoclimatol Palaeoecol 14: 97-118.

Martill DM. 1993. Fossils of the Santana and Crato formations, Brazil. Field Guides to Fossils, 5. The Palaeontological Association, London, $159 \mathrm{p}$.

MARTILl DM. 2007a. The age of the Cretaceous Santana Formation fossil Konservat Lagerstätte of northeast Brazil: a historical review and an appraisal of the biochronostratigraphic utility of its paleobiota. Cretaceous Res 28: 895-920.

MARTILL DM. 2007b. The geology of the Crato Formation. In: MARTILl DM ET AL. (Eds), The Crato fossil beds of Brazil, window to an ancient world, Cambridge University Press, p. 8-24.

Martill DM AND DAVIS PG. 1998. Did dinosaur come up to scratch? Nature 396: 528-529.

Martill DM AND DAVIS PG. 2001. A feather with possible ectoparasite eggs from Crato Formation (Lower Cretaceous, Aptian) of Brazil. N Jb Geol Paläont Abh 219: 241-259.

Martill DM AND Filgueira JBM. 1994. A new feather from the lower Cretaceous of Brazil. Paleontology 37(3): 483-487.

Martill DM AND FREY E. 1995. Colour patterning preserved in Lower Cretaceous birds and insects: the Crato Formation of NE Brazil. N Jb Geol Paläont Abh 2: 118128.

MARTILl DM AND FreY E. 1998. A new pterosaur Lagerstätte in NE Brazil (Crato Formation; Aptian, Lower Cretaceous): preliminary observations. Oryctos 1: 79-85.

MARTILl DM AND WILBY PR. 1993. Stratigraphy. In: MARTILl DM (Ed), Fossils of the Santana and Crato formations, Brazil. Field Guides to Fossils, 5. The Palaeontological Association, London, p. 20-50.

Martins-Neto RG. 2001. Primeiro registro de Trichoptera (Insecta) na Formação Santana (Cretáceo Inferior), Bacia do Araripe, nordeste do Brasil, com descrição de sete novos táxons. In: SiMPÓsio SOBRE A BACIA DO ARARIPE E BACIAS INTERIORES DO NORDESTE, 1 e 2, Crato, 1990/1997. Boletim, p. 212-226.

Martins-Neto RG And Kellner AWA. 1988. Primeiro registro de pena na Formação Santana (Cretáceo Inferior), Bacia do Araripe, nordeste do Brasil. An Acad Bras Cienc 60: 61-68.

Middleton KM And Gatesy SM. 2000. Theropod forelimb design and evolution. Zool J Linn Soc 128: 149-187.

Munro U, Funnell JR And Thompson AS. 2006. Moult in captive partially migratory and sedentary Australian silvereyes (Zosterops lateralis) (Zosteropidae). J Ornithol 147: 287-297.

NAish D, Martill DM AND Merrick I. 2007. Birds of the Crato Formation. In: MARTILL DM (Ed), The Crato fossil beds of Brazil, Cambridge University Press, p. 525533.

NeUmanN VH AND CABRERA L. 1999. Una nueva propuesta estratigrafica para la tectonosecuencia post-rifte de la cuenca de Araripe, noreste de Brasil. In: BOLETIM DO $5^{\circ}$ Simpósio SOBRE O CRETÁCEO do BRASIL, São Paulo, p. 279-285.

Norell MA, Ji Q, GaO KQ, YuAn C, ZhaO Y AND WANG L. 2002. Modern feathers on a non-avian dinosaur. Nature 416: 36-37.

Norell MA And XU X. 2005. Feathered dinosaurs. Annu Rev Earth Planet Sci 33: 277-299.

PADIAN K AND CHIAPPE LM. 1998. The origin and early evolution of birds. Biol Rev 73: 1-42.

Perrichot V, Marion L, Néraudeau D, Vullo R and TAFFOREAU P. 2008. The early evolution of feathers: fossil evidence from Cretaceous amber of France. Proc R Soc B 175: 1197-1202.

Pons D, BerThou PY And CAmpos DA. 1990. Quelques observations sur la palynologie de l'Aptien superieur et de l'Albien du Bassin d'Araripe. In: CAMPOS DA ET AL. (Eds), Atas do Simpósio sobre a Bacia do Araripe e Bacias Interiores do Nordeste, Crato, p. 241-252.

PonTE FC AND APPI CJ. 1990. Proposta de revisão da coluna litoestratigráfica da Bacia do Araripe. Congresso Brasileiro de Geologia, 36, Natal, p. 211-226.

PRUM RO. 1999. Development and evolutionary origin of feathers. J Exp Zool B (Mol. Dev. Evol.) 285: 291-306.

PRUM RO AND BRUSH AH. 2002. The evolutionary origin and diversification of feathers. Q Rev Biol 77: 261-295.

PRUM RO AND DYCK J. 2003. A hierarchical model of plumage: morphology, development, and evolution. J Exp Zool B (Mol. Dev. Evol.) 298: 73-90.

PRUM RO AND Williamson S. 2001. A theory of the growth and evolution of feather shape. J Exp Zool B (Mol. Dev. Evol.) 291: 30-57.

RAYNER JMV. 2001. On the origin and evolution of flapping flight aerodynamics in birds. In: GAUTHIER J AND GAll LF (Eds), New Perspectives on the Origin and Early Evolution of Birds: Proceedings of the international symposium in honor of John H. Ostrom, New Haven, p. 363-385. 
RIETSCHEL S. 1985. Feathers and wings of Archaeopteryx, and the question of her flight ability. In: HECHT MK ET AL. (Eds), The beginnings of birds, Freunde des JuraMuseums, Eichstatt, p. 251-260.

ROHWER S. 2008. A primer on summarizing molt data for flight feathers. Condor 110: 799-806.

Rohwer S, Ricklefs RE, RoHwer VG AND COPple MM. 2009. Allometry of the duration of flight feather molt in birds. PLoS Biol 7(6): 1000132.

RoHWER S AND WANG LK. 2010. A Quantitative Analysis of Flight Feather Replacement in the Moustached Tree Swift Hemiprocne mystacea, a Tropical Aerial Forager. PloS One 5(7): e11586.

Salisbury SW, Frey E, Martill DM and Buchy MC. 2003. A new crocodilian from the Lower Cretaceous Crato Formation of northeastern Brazil. Palaeont Abt A 270: 3-47.

SANTOS RS. 1947. Uma redescrição de Dastilbe elongatus, com algumas considerações sobre o gênero Dastilbe. Divisão de Geologia e Mineralogia, Notas prelimimares e Estudos 42: 1-7.

SAYão JM AND Kellner AWA. 1998. Pterosaur wing with soft tissue from the Crato Member (Aptian-Albian), Santana Formation, Brazil. J Vert Paleontol 18(Suppl 3): 75A.

SAYÃo JM AND Kellner AWA. 2000. Description of a pterosaur rostrum from the Crato Member, Santana Formation (Aptian-Albian) northeastern Brazil. Bol Mus Nac 54: 1-8.

SAYÃo JM AND Kellner AWA. 2006. Novo esqueleto parcial de pterossauro (Pterodactyloidea, Tapejaridae) do Membro Crato (Aptiano), Formação Santana, Bacia do Araripe, nordeste do Brasil. Estudos Geológicos 16: 1640.

Schweigert G, Tischlinger H and Dietl G. 2009. The oldest fossil feather from Europe. N Jb Geol Paläont Abh 256(1): 1-6.

SERENO P. 1999. The Evolution of Dinosaurs. Science 284: 2137-2147.

Shufeldt RW. 1916. A fossil feather from Taubaté. Auk 33: 206-207.

Silva SANTOS R. 1950. Vestígio de ave fóssil nos folhelos betuminosos de Tremembé, São Paulo. An Acad Bras Cienc 22(4): 445-446.

SMALL H. 1913. Geologia e suprimento de agua subterrânea no Ceará e parte do Piauí. Inspetoria de Obras Contra Secas, Série Geologia 25: 1-180.

SPEER B. 2006. Ratite medicine and surgery. In: ProceEd-
INGS OF THE NORTH AMERICAN VETERINARY CONFERENCE, 20, p. 1593-1597.

Stresseman E and Stresseman V. 1966. Die Mauser der Vogel. J Ornithol 107: 1-445.

STRONG RM. 1902. The development of color in the definitive feather. Mus Comp Zool 40: 147-385.

Valença LMM, Neumann VH and Mabesoone JM. 2003. An overview on Calloviane Cenomanian intracratonic basins of northeast Brazil: onshore stratigraphic record of the opening of the southern Atlantic. Geol Acta 1: 261-275.

Viana MSS AND NeumanN VHL. 2002. Membro Crato da Formação Santana, Chapada do Araripe, CE. Riquíssimo registro de fauna e flora do Cretáceo. In: SCHOBBenhaus C, CAmpos DA, Queiroz ET, Winge M AND Born MLCB (Eds), Sítios Geológicos e Paleontológicos do Brasil. DNPM/CPRM/SIGEP, Brasília, p. 113-120.

Vinther J, Briggs DEG, Clarke J, Mayr G AND Prum RO. 2010. Structural coloration in a fossil feather. Biol Lett 6: 128-131.

Vinther J, BRiggs DEG, PRUM RO AND SARANATHAN V. 2008. The colour of fossil feathers. Biol Lett 4: 522525 .

Wellnhofer P. 1985. Neue Pterosaurier aus der Santana Formation (Apt) der Chapada do Araripe, Brasilien. Palaeontographica A 187: 105-182.

Wellnhofer P. 1991. Weitere Pterosaurierfunde aus der Santana-Formation (Apt) der Chapada do Araripe, Brasilien. Palaeontographica A 215: 43-101.

WitTon MP. 2008. A new azhdarchoid pterosaur from the Crato Formation (Lower Cretaceous, Aptian?) of Brazil. Palaeontology 51(6): 1289-1300.

XU X. 2006. Feathered dinosaurs from China and the evolution of major avian characters. Integr Zool 1: 4-11.

XU X, TANG Z AND WANG X. 1999a. A therizinosaurid dinosaur with integumentary structures from China. Nature 399: 350-354.

Xu X, WANG XL AND Wu XC. 1999b. A dromeosaurid dinosaur with a filamentous integument from the Yixian Formation of China. Nature 401: 262-266.

Xu X, Zheng X And You H. 2009. A new feather type in a nonavian theropod and the early evolution of feathers. PNAS 106(3): 832-834.

Xu X, Zheng X and You H. 2010. Exceptional dinosaur fossil show ontogenetic development of early feathers. Nature 464: 1338-1341. 
Xu X, Zhou Z And Prum RO. 2001. Branched integumental structures in Sinornithosaurus and the origin of feathers. Nature 410: 200-204.

XU X, Zhou Z And WAnG XL. 2000. The smallest known non-avian theropod dinosaur. Nature 408: 705-708.

Xu X, Zhou Z, WANG XL, KuAng X, Zhang F AND DU X. 2003. Four-winged dinosaurs from China. Nature 421: $335-340$.

ZHOU Z. 2004. The origin and early evolution of birds: discoveries, disputes, and perspectives from fossil evidence. Naturwissenschaften 91: 455-471.
Zhou Z, BARRett PM And Hilton J. 2003. An exceptionally preserved Lower Cretaceous ecosystem. Nature 421: 807-814.

ZHOU Z AND WANG XL. 2000. A new species of Caudipteryx from the Yixian Formation of Liaoning, Northeast China. Vertebr PalAsiatica 38(2): 111-127.

ZhOU Z, WANG X, ZHANG F AND XU X. 2000. Important features of Caudipteryx: evidence from two nearly complete new specimens. Vertebr PalAsiatica 38(4): 241-254. 